\title{
Effect of Origanum vulgare Extract on Immune Responses and Heamatological Parameters of Rainbow Trout (Oncorhynchus mykiss)
}

\author{
Masoud Haghighi*1, Hamid Pourmoghim² ${ }^{2}$ and Mostafa Sharif Rohani ${ }^{3}$ \\ ${ }^{1}$ Cold-water Fishes Research Center, Iranian Fisheries Science Research Institute, Agricultural Research, Education and Extension Organization \\ (AREEO), Iran
}

${ }^{2}$ Department of Veterinary Basic Sciences, Islamic Azad University, Iran

${ }^{3}$ Iranian Fisheries Science Research Institute, Iran

Submission: December 13, 2017; Published: February 15, 2018

*Corresponding author: Masoud Haghighi, Coldwater Fishes Research Center, Iranian Fisheries Science Research Institute, Agricultural Research, Education and Extension Organization (AREEO), Tonekabon, Iran, Tel: +98-192-4562227; Email: masoud126@yahoo.com

\begin{abstract}
In this study, Origanum vulgare extract was used to evaluate its effects on immune responses and hematological parameters of rainbow trout (Oncorhynchus mykiss). Six hundred (600) averages mean weight $13 \pm 0.05 \mathrm{~g}$ rainbow trout (Oncorhynchus mykiss) were randomly allocated into two groups including placebo-treated group (control), and Origanum vulgare extract-treated group, each of three replicates. The fishes were hand-fed once a day with diet medicated placebo or Origanum vulgare extract (OE) at a rate of $1 \%$ of feed weight in the first feeding for 8 weeks. At the end of every two weeks $24 \mathrm{hrs}$ after feeding, fish were bled from caudal vein and blood samples were analyzed for some of hematological and immunological parameters. The results showed that serum total protein, albumin and globulin, respiratory burst activity, phagocytic activity and serum lysozyme activity vary among the two treatment groups which were found to be higher in OE-treated group ( $\mathrm{P}<0.05)$. It was concluded that supplementation of $\mathrm{OE}$ at a rate of $1 \%$ registered higher immunological responses. Therefore, dietary inclusion of OE could improve nonspecific immune responses in rainbow trout. Future studies to determine optimal herb mixtures and dietary levels should be conducted.
\end{abstract}

Keywords: Herbal immunostimulant; Iranian medicinal plants; Origanum vulgare; Fish

\section{Introduction}

Major targets in the aquaculture industry are to maintain fish health as well as to improve fish performance. The use of plant extracts in practical diets for fish is a very topical concept in aquaculture industry. One of the most important aspects in rainbow trout farming is the nutrition factor. It can influence the performance as well as the health status of the cultured fish. Origanum vulgare is a member of the Labiatae family of plants. It is an aromatic plant with a wide distribution throughout the Mediterranean area and Asia [1]. The essential oil obtained from $O$. vulgare subsp. hirtum plant by a steam distillation process comprises more than 20 ingredients, most of which are phenolic antioxidants [2]. Major components are carvacrol and thymol that constitute about 78 to $82 \%$ of the total oil [3]. It has been suggested that the essential oil derived from oregano possess in vitro antimicrobial [4,5] antifungal [6], insecticidal [7] and antioxidant [8] properties. These properties are mainly attributed to carvacrol and thymol. The activity of other constituents such as the two monoterpene hydrocarbons, $\gamma$-terpinene and p-cymene, that often constitute about 5 and $7 \%$ of the total oil, respectively [3] is uncertain.

Materials and Methods

\section{Preparation of Origanum vulgare extract}

The plant of Origanum vulgare was procured from local store and plant species was identified and confirmed by a botanist in Institute of Medicinal Plants. The dried air parts were collected and washed in sterile distilled water. The samples were separately shade-dried for 10 day till weight constancy was achieved. Then, the samples were powdered in an electric blender. The extract was prepared with the standard method of percolation. To do this, chopped dried air parts of plant in $80 \%$ ethanol were percolated for 72 hours. Then, the slurry was filtered with Whattman No. 1 filter paper and centrifuged for $5 \mathrm{~min}$ at $5000 \mathrm{rpm}$. The filtrate obtained from ethanol using a rotary device, the excess solvent was separated from the extract. These crude extract was stored at $4{ }^{\circ} \mathrm{C}$ until use. 


\section{Supplementation of the normal diet with dried Origanum vulgare extract}

The formulated fish feed was prepared using the normal fish diet (50\% crude protein, $18 \%$ crude lipid, $1.9 \%$ fiber, $1.3 \%$ total phosphorus, $8.3 \%$ ashes, and $14.8 \%$ nitrogen free extract) with dried Origanum vulgare extract or placebo at a ratio $1 \%$ of weight food and mixing part by part in a drum mixer. Sufficient water along with the oil ingredients were then added to make a paste of each diet. After it was pelleted and allowed to cool dry. The pellets were air dried and stored in air tight containers until fed.

\section{Fish and experimental conditions}

600 rainbow trout weighing $13 \pm 0.05$ were used. All experiments were carried out in 1,000 liter round concrete ponds with a continuous water flow of 2.5 liter per second. The fish were kept at an ambient, including uncontrolled water temperature of $15 \pm 1{ }^{\circ} \mathrm{C}$, dissolved oxygen of $7.2 \pm 0.2 \mathrm{mg} \mathrm{l}^{-1}$ and $\mathrm{pH} 8 \pm 0.3$. After 2 weeks adaptation, fish were randomly allotted in two groups including an experimental group and a control group, in triplicate was maintained in 6 concrete ponds each containing 100 fish. Each group was hand-fed once a day with diet medicated $1 \%$ of Origanum vulgare extract, or placebo (70\% lactose, $10 \%$ starch and $20 \%$ talc) prepared in the laboratory and three times with normal diet at a rate $2 \%$ of body weight for 10 weeks.

\section{Bleeding and serum collection}

During bleeding, fish were rapidly netted, tranquillized with $50 \mathrm{mg} / \mathrm{l}$ of tricaine methane sulfonate $\left(\mathrm{MS}_{222}\right.$, Sigma chemical Co. St. Louis, MO, USA). Fish were bled from caudal vein using $1 \mathrm{ml}$ insulin syringe fitted with 24 gauge needle. To minimize the stress to fish, $1 \mathrm{ml}$ of blood was drawn and the whole bleeding procedure was completed within $1 \mathrm{~min}$. A total number of 15 blood samples were collected from 15 fish in each group (5 samples from each replicate) at the end of every 2 weeks, $24 \mathrm{~h}$ after final feeding period. The blood pooling of 5 fish from each replicate divided into 2 haves. Half collected in serological tubes containing a pinch of lithium heparin powder, shaken gently and kept at $4{ }^{\circ} \mathrm{C}$ to test hematological parameters. Other half collected in tubes without of anticoagulant and allowed to clot at $4{ }^{\circ} \mathrm{C}$ for $2 \mathrm{hrs}$ to test serological parameters. The clot was the spun down at $2000 \mathrm{rpm}$ for $10 \mathrm{~min}$ to separate the serum. The serum collected by micropipette and was stored in sterile Eppendorf tubes at $-20^{\circ} \mathrm{C}$ until used for assay.

\section{Hematological assay}

Blood sample was analyzed with routine methods adopted in fish hematology [9]. The total red blood cell counts (RBC $\times 10^{6} / \mu \mathrm{l}$ ) were determined in a 1:200 dilution of the blood sample in Hayem's solution and total white blood cell counts $\left(\right.$ WBC $\left.\times 10^{3} / \mu \mathrm{l}\right)$ in a $1: 20$ dilution of the blood sample with a Neubauer hemocytometer. The hematocrit (Hct) and leucocrit percentages were determined in duplicate by using micro hematocrit-heparinized capillary tubes of $75 \mu \mathrm{l}$ volume and a micro hematocrit centrifuge at $15000 \mathrm{rpm}$ for $5 \mathrm{~min}$ [10]. The percentages of erythrocyte (hematocrit) and leucocyte (leucocrit) volumes were calculated by overlaying the tubes on a sliding scale hematocrit reader.

The hemoglobin (Hbg/dl) concentrations were determined by the cyanomethaemoglobin method [11] using a haemoglobin reagent set (Ziest Chem Diagnostics). The all the values of red blood cell indices, the mean values of cell haemoglobin (MCH pg), cell hemoglobin concentration (MCHC \%), and cell hemoglobin volume ( $\mathrm{MCV}$ fl) were calculated according to Wintrobe formulae [12]. The differential leukocytes count was carried out using blood smears stained with Wright-Giemsa. The percentage composition of leukocytes was determined based on their identification characters listed by Ivanava [13].

\section{Biochemical assay}

Serum total protein content was estimated photo metrically by citrate buffer and bromocresol green (BCG) dye binding method [14] using the kit (total protein and albumin kit, Pars Azmun Company, Iran). Albumin was determined BCG binding method. The absorbance of standard and test were measured against blank in a spectrophotometer at $546 \mathrm{~nm}$. Globulin level was calculated by subtracting albumin values from total serum protein. Albumin/globulin (A/G) ratio was calculated by diving albumin values by globulin values.

\section{Immunological assay}

\section{Separation of leukocytes from the blood}

Leucocytes for assay were separated from each blood sample by density-gradient centrifugation. One milliliter of histopaque 1.119 (Sigma) containing $100 \mu \mathrm{l}$ of bactohemagglutination buffer, pH 7.3 (Difco, USA) was dispensed into siliconised tubes. $1 \mathrm{ml}$ of a mixture of 1.077 density histopaque and hemagglutination buffer and $1 \mathrm{ml}$ of blood was carefully layered on the top. The sample preparations were centrifuged at $2500 \mathrm{rpm}$ for $15 \mathrm{~min}$ at $4{ }^{\circ} \mathrm{C}$. After centrifugation, plasma was collected and stored at -80 ${ }^{\circ} \mathrm{C}$ for future analysis; separated leukocytes were gently removed and dispensed into siliconised tubes, containing phenol red free Hanks Balanced Salt Solution (HBSS, Sigma). Cells were then washed twice in HBSS and adjusted to $2 \times 10^{6}$ viable cells $/ \mathrm{ml}$.

\section{Respiratory burst activity}

Respiratory burst activity of isolated leukocytes was quantified by reduction of ferricytochrome C [15]. Briefly, $100 \mu \mathrm{l}$ of leukocyte suspension and an equal volume of cytochrome $\mathrm{C}$ ( $2 \mathrm{mg} / \mathrm{l}$ in phenol red free HBSS) containing phorbol 12-myristate 13 -acetate (PMA, Sigma) at $1 \mu \mathrm{g} / \mathrm{ml}$ were placed in triplicate in micro titer plates. In order to test specificity, another $100 \mu \mathrm{l}$ of leukocyte suspensions and solutions of cytochrome c containing PMA and superoxide dismutase (SOD, Sigma) at 300U/ml 
were prepared in triplicate in micro titer plates. Samples were then mixed and incubated at room temperature for $15 \mathrm{~min}$. Extinctions were measured at $550 \mathrm{~nm}$ against a cytochrome C blank in a multiscan spectrophotometer. Readings were converted to nmoles $\mathrm{O}_{2}$ by subtracting the O.D. of the PMA/SOD treated supernatant from that treated with PMA given alone for each sample, and converting O.D. to $\mathrm{n}$ moles $\mathrm{O}_{2}$ by multiplying by 15.87. Final results were expressed as nano moles $\mathrm{O}_{2}$ produced per $10^{5}$ blood leukocytes.

\section{Phagocytosis assay}

Phagocytosis activity of blood leukocytes was determined spectrophotometrically according to Seeley et al. [16]. This assay involves the measurement of congo red-stained yeast cells which have been phagocytised by cells. To perform the assay, $250 \mu \mathrm{l}$ of the leukocyte solution was mixed with $500 \mu$ l of the congo redstained and autoclaved yeast cell suspension (providing a yeast cell: leukocyte ratio of 40:1). The mixtures were incubated at room temperature for $60 \mathrm{~min}$. Following incubation, $1 \mathrm{ml}$ ice-cold HBSS was added and $1 \mathrm{ml}$ of histopaque (1.077) was injected into the bottom of each sample tube. The samples were centrifuged at $2500 \mathrm{rpm}$ for $5 \mathrm{~min}$ to separate leukocytes from free yeast cells. Leukocytes were harvested and washed two times in HBSS. The cells then were resuspended in $1 \mathrm{ml}$ trypsin-EDTA solution (5.0g/l trypsin and 2.0g/l EDTA, Sigma) and incubated at 37 ${ }^{\circ} \mathrm{C}$ overnight. The absorbance of the samples was measured at $510 \mathrm{~nm}$ using trypsin-EDTA as a blank.

\section{Serum lysozyme assay}

In this study, an assay based on the lysis of Micrococcus lysodeikticus was used to determining the lysozyme activity.
Serum lysozyme activity was measured spectrophotometrically according to the method Parry et al. [17]. Briefly, 0.02\% (w/v) lyophilized Micrococcus lysodeikticus in $0.05 \mathrm{mM}$ solution phosphate buffer ( $\mathrm{pH}$ 6.2) was used as substrate. $10 \mu \mathrm{l}$ of fish serum was added to $250 \mu \mathrm{l}$ of bacterial suspension and reduction in absorbance at $490 \mathrm{~nm}$ was determined after 0.5 and $4.5 \mathrm{~min}$ of incubations at $25{ }^{\circ} \mathrm{C}$ using a microplate reader. One unit of lysozyme activity was defined as the amount of enzyme causing a decrease in absorbance of 0.001 per min.

\section{Statistical analysis}

All results for each parameter measured were expressed as means \pm standard errors, and were compared at each time point using Student's t-test for independent data. Significant differences between experimental groups were expressed at a significance level of $\mathrm{P}<0.05$. All analyses were carried out on 15 fish per group.

\section{Results}

\section{Hematological analysis}

Dietary Origanum vulgare extract incorporated test diets had no significant $(\mathrm{p}<0.05)$ effect on red blood cell count $(\mathrm{RBC})$, white blood cell count (WBC), differential leukocytes count (monocyte, lymphocyte and neutrophile), hematocrit (Hct), hemoglobin $(\mathrm{Hb})$, the all the values of red blood cell indices, the mean values of cell hemoglobin ( $\mathrm{MCH}$ pg), cell hemoglobin concentration ( $\mathrm{MCHC} \%$ ), and cell hemoglobin volume (MCV fl) at the end of none of the identical two weeks after feeding in compared to placebo group (Table 1).

Table 1: The haematological parameters, WBC, RBC, Hct, $\mathrm{Hb}, \mathrm{MCH}, \mathrm{MCV}, \mathrm{MCHC}$, neutrophil, monocyte, and lymphocyte of rainbow trout fed with $1 \%$ placebo $(\mathrm{PL})$ or Origanum vulgare extract $(\mathrm{OE})$ in feed for 8 weeks.

\begin{tabular}{|c|c|c|c|c|c|c|c|c|c|c|c|}
\hline Week & Groups & $\begin{array}{c}\text { WBC } \\
(103 / \\
\mathrm{mL})\end{array}$ & $\begin{array}{c}\text { RBC } \\
(106 / \mathrm{mL})\end{array}$ & Hct(\%) & $\mathrm{Hb}(\mathrm{g} / \mathrm{dL})$ & MCH(pg) & $\operatorname{MCV}(\mathrm{fL})$ & MCHC(\%) & Neut(\%) & Mon(\%) & Lymp(\%) \\
\hline \multirow{2}{*}{2} & PL & $3.90 \pm 0.7$ & $0.98 \pm .06$ & $27.33 \pm 3.3$ & $9.07 \pm 0.6$ & $92.55 \pm 2.7$ & $278.8 \pm 16$ & $3.31 \pm 0.34$ & $7.66 \pm 0.1$ & $3.00 \pm 0.3$ & $89.0 \pm 1.2$ \\
\hline & $\mathrm{OE}$ & $3.92 \pm 0.2$ & $1.08 \pm .08$ & $27.77 \pm 2.2$ & $9.32 \pm 0.9$ & $86.29 \pm 4.6$ & $257.1 \pm 11$ & $3.35 \pm 0.5$ & $8.33 \pm 0.1$ & $2.66 \pm 0.1$ & $90.0 \pm 1.0$ \\
\hline \multirow{2}{*}{4} & PL & $4.00 \pm 0.1$ & $1.69 \pm .05$ & $40.50 \pm 4.1$ & $13.50 \pm 0.9$ & $79.88 \pm 3.1$ & $239.6 \pm 13$ & $3.33 \pm 0.3$ & $7.66 \pm 0.5$ & $2.33 \pm 02$ & $89.0 \pm 2.0$ \\
\hline & $\mathrm{OE}$ & $4.06 \pm 0.6$ & $1.71 \pm .04$ & $40.50 \pm 5.5$ & $13.56 \pm 1.5$ & $79.29 \pm 2.9$ & $236.8 \pm 9$ & $3.34 \pm 0.4$ & $7.66 \pm 0.4$ & $2.00 \pm 0.5$ & $90.3 \pm 0.7$ \\
\hline \multirow{2}{*}{6} & PL & $4.20 \pm 0.5$ & $1.69 \pm .03$ & $36.00 \pm 3.7$ & $12.00 \pm 1.5$ & $71.00 \pm 3.0$ & $213.0 \pm 6$ & $3.33 \pm 0.3$ & $7.66 \pm 0.3$ & $3.33 \pm 03$ & $89.0 \pm 2.1$ \\
\hline & $\mathrm{OE}$ & $4.10 \pm 0.2$ & $1.76 \pm .06$ & $37.00 \pm 2.0$ & $12.06 \pm 0.8$ & $68.52 \pm 1.9$ & $210.2 \pm 6$ & $3.25 \pm 0.2$ & $8.33 \pm 0.2$ & $3.00 \pm 0.2$ & $88.6 \pm 0.9$ \\
\hline \multirow{2}{*}{8} & PL & $4.95 \pm 0.1$ & $1.53 \pm .03$ & $33.00 \pm 3.5$ & $10.98 \pm 1.8$ & $71.76 \pm 3.9$ & $215.6 \pm 8$ & $3.32 \pm 0.2$ & $8.00 \pm 0.1$ & $2.33 \pm 0.2$ & $89.6 \pm 1.2$ \\
\hline & $\mathrm{OE}$ & $5.31 \pm 0.5$ & $1.46 \pm .06$ & $36.66 \pm 3.0$ & $12.33 \pm 1.3$ & $84.45 \pm 4.1$ & $251.0 \pm 14$ & $3.36 \pm 0.3$ & $7.66 \pm 0.5$ & $2.00 \pm 0.6$ & $90.0 \pm 0.6$ \\
\hline
\end{tabular}

Data are expressed as mean $\pm S E(n=15)$. No significant differences were observed in the Origanum vulgare treated groups relative to the placebo group at the end of the identical every two weeks after feeding $(P>0.05)$. Neut: neutrophil; Mon: Monocyte; Lymp: Lymphocyte.

\section{Biochemical analysis}

Origanum vulgare extract had significant $(\mathrm{p}<0.05)$ effect in increase of total protein (TP), albumin (AL), and globulin (GL), at the end of the identical every two weeks after feeding in compared to placebo group (Table 2). The maximum level of total protein was recorded on week 2 of exposure duration. Similarly, albumin and globulin contents were significantly higher in Aloe vera group as compared to placebo group. However, albumin/ 
globulin ratio was not exhibited significant differences in

two weeks after feeding in compared to placebo group $(\mathrm{p}>0.05$; compared to placebo group at the end of the identical every

Table 2).

Table 2: Changes in the serum total protein, albumin, globulin and albumin/globulin ratio of rainbow trout after feeding with $1 \%$ placebo, or Origanum vulgare extract for 8 weeks.

\begin{tabular}{|c|c|c|c|c|c|}
\hline \multirow{2}{*}{ Week } & Groups & Total protein $\mathbf{( g / d L )}$ & Albumin (g/dL) & Globulin (g/dL) & $\begin{array}{c}\text { Albumin/globulin } \\
\text { ratio (g/dL) }\end{array}$ \\
\hline \multirow{2}{*}{2} & Placebo & $4.10 \pm 0.01$ & $1.80 \pm 0.08$ & $2.20 \pm 0.08$ & $0.81 \pm 0.01$ \\
\cline { 2 - 6 } & Origanum extract & $4.23 \pm 0.01$ & $1.90 \pm 0.07$ & $2.33 \pm 0.03$ & $0.81 \pm 0.02$ \\
\hline \multirow{2}{*}{4} & Placebo & $4.03 \pm 0.01$ & $1.80 \pm 0.04$ & $2.23 \pm 0.08$ & $0.80 \pm 0.02$ \\
\cline { 2 - 6 } & Origanum extract & $4.26 \pm 0.02^{*}$ & $1.90 \pm 0.05^{*}$ & $2.36 \pm 0.04$ & $0.80 \pm 0.02$ \\
\hline \multirow{2}{*}{6} & Placebo & $3.40 \pm 0.02$ & $1.53 \pm 0.06$ & $1.87 \pm 0.01$ & $0.81 \pm 0.01$ \\
\cline { 2 - 6 } & Origanum extract & $3.80 \pm 0.04^{*}$ & $1.73 \pm 0.03^{*}$ & $2.07 \pm 0.06^{*}$ & $0.83 \pm 0.01$ \\
\hline \multirow{2}{*}{8} & Placebo & $3.93 \pm 0.01$ & $1.75 \pm 0.06$ & $2.18 \pm 0.03$ & $0.80 \pm 0.01$ \\
\cline { 2 - 6 } & Origanum extract & $4.19 \pm 0.02$ & $1.89 \pm 0.05^{*}$ & $2.30 \pm 0.05^{*}$ & $0.82 \pm 0.01$ \\
\hline
\end{tabular}

Data are expressed as mean \pm SE $(n=15)$. *: $P<0.05$ compared with the placebo at the end of identical every two weeks.

\section{Immunological analysis}

\section{Respiratory burst activity}

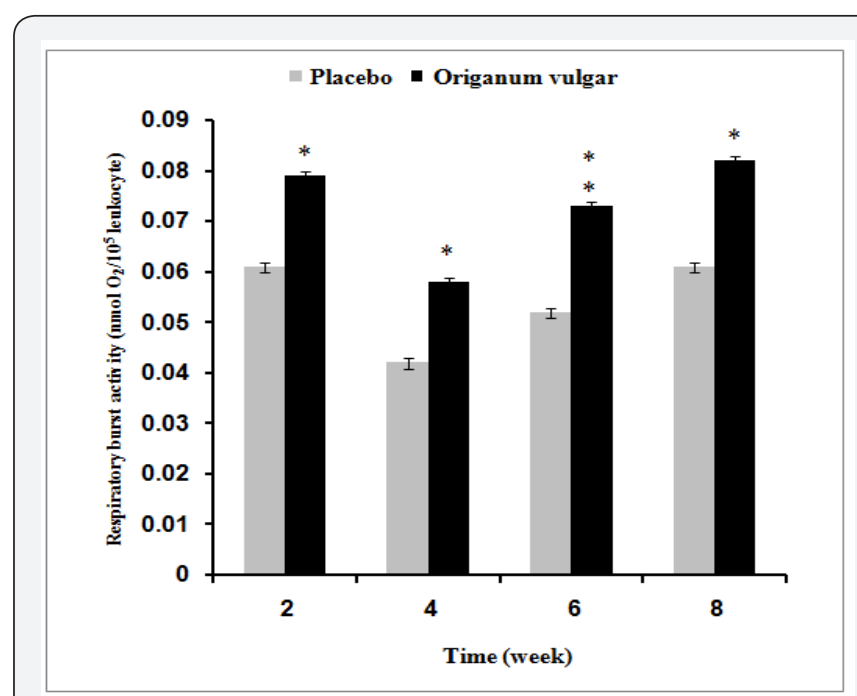

Figure 1: Respiratory burst activity of different experimental groups observed on different weeks. Data are expressed as mean $\pm S E$. Asterisks indicate significantly different from placebo group in the same week. ${ }^{*} p<0.05 ;{ }^{* *} p<0.001$.

The respiratory burst activity significantly $(\mathrm{p}<0.05)$ enhanced in fish fed with $1 \%$ of Origanum vulgare extract supplementation feed at the end of the identical every two weeks after feeding in compared to placebo group (Figure 1).

\section{Lysozyme activity}

Lysozyme activity significantly $(\mathrm{p}<0.05)$ enhanced in fish fed with $1 \%$ of Origanum vulgare extract supplementation feed

\section{Phagocytic activity}

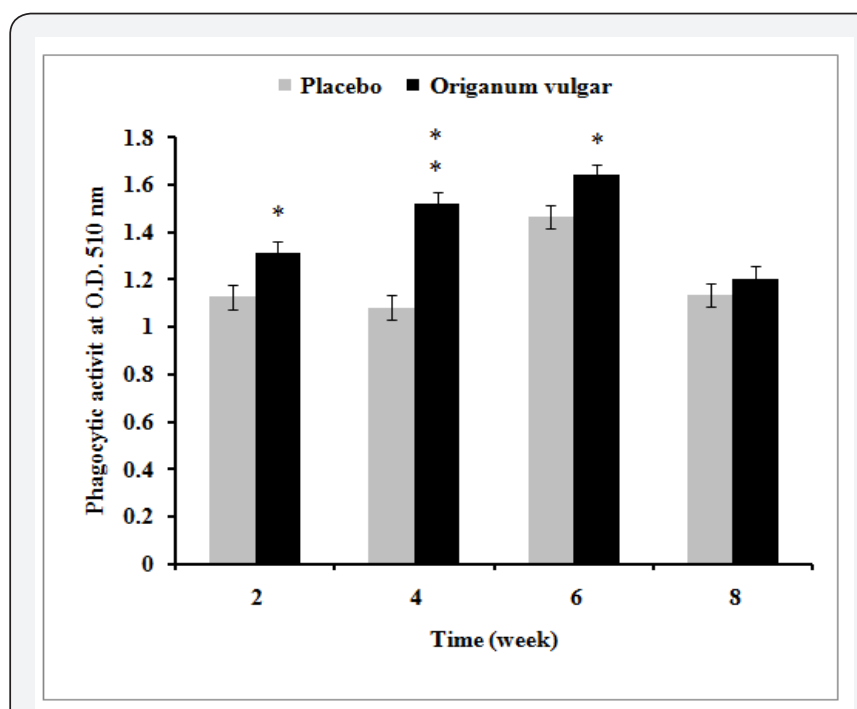

Figure 2: Phagocytic activity of different experimental groups observed on different weeks. Data are expressed as mean \pm SE. Asterisks indicate significantly different from placebo group in the same week. ${ }^{*} p<0.05 ;{ }^{* *} p<0.001$.

Phagocytic activity of blood leucocytes significantly $(\mathrm{p}<0.05)$ enhanced in fish treated with $1 \%$ of Origanum vulgare extract supplementation feed at the end of the identical every two weeks after feeding in compared to placebo group (Figure 2).

at the end of the identical every two weeks after feeding in compared to placebo group (Figure 3). 


\section{Oceanography \& Fisheries Open access Journal}

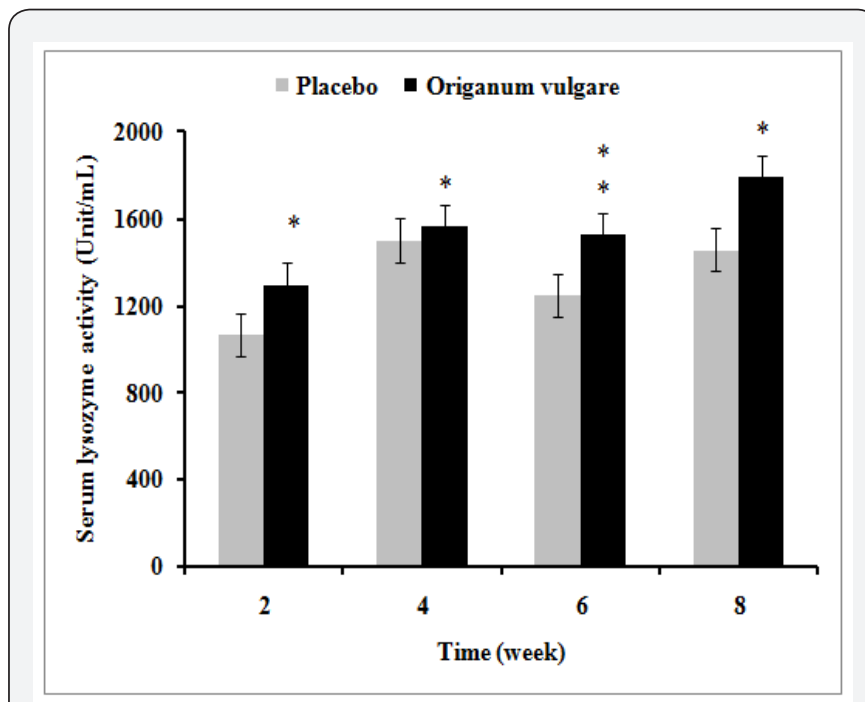

Figure 3: Serum lysozyme activity of different experimental groups observed on different weeks. Data are expressed as mean \pm SE. Asterisks indicate significantly different from placebo group in the same week. ${ }^{*} p<0.05 ;{ }^{* *} p<0.001$.

\section{Discussion}

The present study projects the impact of dried Origanum vulgare extract on the hematological and immunological responses in rainbow trout (Oncorhyncous mykiss). The hematological parameters in the present investigation such as RBC, WBC, differential leukocytes counts, hemoglobin, hematocrit, the all of the values of red blood cell indices $(\mathrm{MCH}$, MCHC and MCV) were no significant differences at the end of none of the identical every two weeks after feeding when compared to control group. These observations are in agreement with the obtained results of other researchers, who reported that rainbow trout treated with dietary Aloe vera supplementation were no significant differences in RBC and Hct [18], or RBC and $\mathrm{Hb}$ [19] among the groups.

In the present study, the dietary Origanum vulgare extract supplementation enhanced total plasma protein, albumin and globulin values in comparison with control group. Similar results were reported in rainbow trout fed with garlic [20], ginger [21], lipopolysaccharide [22], Laurus nobilis [23], and Coggyria coggyria [24]. Serum proteins are various humoral elements of the non-specific immune system, measurable total protein, albumin and globulin levels suggest that high concentrations are likely to be a result of the enhancement of the non-specific immune response of fish. So, this study revealed that Origanum vulgare extracts incorporated diets helped to increase the humoral elements in the serum. Respiratory burst activity is considered as an important indicator of non-specific defense in fish, which is a measure of the increase of oxidation level in phagocytes stimulated by foreign agents [25]. An enhancement of respiratory burst activity has been identified in the present study, that it is in agreement many of studies with dietary immunostimulants $[23,26]$. Respiratory burst and phagocytosis response by phagocytes in blood present a major antibacterial defense mechanism in fish [27]. Phagocytosis is one of the most important processes in fish. The main cells involved in phagocytosis in fish are neutrophils and macrophages. These cells remove bacteria mainly by the production of reactive oxygen species (ROS) during a respiratory burst. In addition, neutrophils possess myeloperoxidase in their cytoplasmic granules, which in the presence of halide and hydrogen peroxidase kills bacteria by halogenations of the bacterial cell wall. Moreover, these cells have lysozymes and other hydrolytic enzymes in their lysosomes [28]. Similarly, macrophages can produce nitric oxide in mammals and can be as potent as antibacterial agents, peroxynitrates and hydroxyl groups. Phagocytic activity of leucocytes in rainbow trout was enhanced by dietary dose of powdered ginger rhizome $[29,30]$. Also, in this study an increasing trend in lysozyme activity has been shown which is in agreement with several reports indicating the role of herbal immunostimulants in enhancing lysozyme activity [31-33]. Lysozyme is a humoral component of the non-specific defense mechanism which has the ability to prevent the growth of bacteria by splitting $\beta-1,4$ glycosidic bonds in the peptidoglycan of bacterial cell walls, resulting in bacteriolysis. In conclusion, supplementation of $\mathrm{OE}$ in aquaculture diets would be use to enhance non-specific immune system in fish. Therefore, further studies are necessary for effective use of Origanum vulgare extract with optimal dose, suitable duration, and method of administration.

\section{Acknowledgement}

The authors would like to thank the Iranian Fisheries Research Organization (IFRO) for the financial support.

\section{Funding}

Foundation project supported by Iranian Fisheries Science Research Institute (IFSRI), Tehran-Iran with grant number: 1412-12-8913-89153.

\section{References}

1. Vokou S, Kokkini S, Bessiere JM (1993) Geographic variation of Greek oregano (Origanum vulgare subsp. hirtum) essential oils. Biochem Syst Ecol 21: 287-295.

2. Vekiari SA, Oreopoulou V, Tzia C, Thomopoulos CD (1993) Oregano flavonoids as lipid antioxidants. J Am Oil Chem Soc 70(5): 483-487.

3. Adam K, Sivropoulou A, Kokkini S, Lanaras T, Arsenakis M (1998) Antifungal activities of Origanum vulgare ssp. Hirtum, Menthaspicata, Lavandula angustifolia, and Salvia fruticosa essential oils against human pathogenic fungi. J Agric Food Chem 46: 1739-1745.

4. Sivropoulou A, Paranikolaou E, Nikolaou C, Kokkini S, Lanaras T, et al. (1996) Antimicrobial and cytotoxic activities of Origanum essential oils. J Agric Food Chem 44: 1202-1205.

5. Lambert RJW, Skandamis PN, Coote PJ, Nychas GJE (2001) A study of the minimum inhibitory concentration and mode of action of oregano essential oil, thymol and carvacrol. J Appl Microbiol 91(3): 453-462.

6. Kocić-TSD, Dimić GR, Tanackov IJ, Pejin DJ, Mojović LV, et al. (2012) Antifungal activity of Oregano (Origanum vulgare L.) extract on the 
growth of Fusarium and Penicillium species isolated from food. Hem Ind 66(1): 33-41.

7. Karpouhtsis I, Pardali E, Feggou E, Kokkini S, Scouras ZG, Mavragani-TP (1998) Insecticidal and genotoxic activities of oregano essential oils. J Agric Food Chem 46: 1111-1115.

8. Botsoglou NA, Florou-PP, Christaki E, Fletouris DJ, Spais AB (2002) Effect of dietary oregano essential oil on performance of chickens and on iron-induced lipid oxidation of breast, thigh and abdominal fat tissues. Br Poult Sci 43(2): 223-230.

9. Blaxhall PC, Daisley KW (1973) Routine haematological methods for use with fish blood. J Fish Biol 5(6): 771-781.

10. Goldenfarb BP, Bowyer FP, Hall T, Brosious E (1971) Reproductibility in the hematology laboratory: the microhematocrit determination. Am J Clin Patholo 56(1): 35-39.

11. Valery H, Gowenblock AH, Bell M (1991) Practical clinical biochemistry. ( $5^{\text {th }}$ edn), CBS Publication and distributors, Dehli, India, pp. 479-480.

12. Wintrobe MM (1933) Variation in size and hemoglobin concentration of erythrocyte in the blood of various vertebrates. Folia Haemato 51: 32-49.

\section{Ivanova NT (1983) Atlas of Fish Blood Cells. LPP Mosacow, Russia.}

14. Shaziya BI, Goyal PK (2012) Anthelmintic effect of natural plant (Carica papaya) extract against the gastrointestinal nematode, Ancylostoma caninum in mice. ISCA J Biological Sci 1(1): 2-6.

15.Secombes CJ (1990) Isolation of salmonid macrophages and analysis of their killing activity. In: Stolen JS, Anderson DP, Roberston BS, van Muiswinkel WB (Eds.), Techniques in fish immunology. SOS Publications, Fair Haven, USA, p. 137-154.

16. Seeley KR, Gillespie PD, Weeks BA (1990) A simple technique for the rapid spectrophotometric determination of phagocytosis by fish macrophages. Mar Environb Res 30: 37-41.

17. Parry RM, Chandan RC, Shahani KM (1965) A rapid and sensitive assay of muramidase. Proc Soc Exp Biol Med 119: 384-386.

18. Alishahi M, Ranjbar MM, Ghorbanpour M, Mesbah M, Razi JM, et al. (2010) Effects of dietary Aloe vera on some specific and nonspecific immunity in the common carp (Cyprinus carpio). Int J Vet Res 4: 189195

19. Farahi A, Kasiri M, Sudagar M, Soleimani IM, Zorriehzahra SMJ (2012) Effect of dietary supplementation of Melissa Officinalis and Aloe Vera on hematological traits, lipid oxidation of carcass and performance in rainbow trout (Oncorhynchus mykiss). Online J Animal Feed Res 1: 1-5.

20. Nya EJ (2009) Studies on dietary supplements for the control of Aeromonas hydrophila infection in rainbow trout (Oncorhynchus mykiss, Walbaum). Doctor of Philosophy thesis. School of Life Sciences, Heriot Watt University, Edinburgh, UK.

21. Nya EJ, Austin B (2009) Use of garlic, Alium sativum, to control Aeromonas hydrophila infection in rainbow trout, Oncorhynchus mykiss (Walbaum). J Fish Dis 32(11): 963-970.

22. Nya EJ, Austin B (2009) Use of dietary ginger, Zingiber officinale Roscoe, as an immunostimulant to control Aeromonas hydrophila infections in rainbow trout, Oncorhynchus mykiss (Walbaum). J Fish Dis 32(1): 971977.

23. Bilen S, Bulut M (2010) Effects of Laurel (Laurus nobilis) on the nonspecific immune responses of rainbow trout (Oncorhynchus mykiss, Walbaum). J Anim Vet Adv 9(8): 1275-1279.

24. Bilen S, Bulut M, Bilen AM (2011) Immunostimulant effects of Coggyria coggyria on rainbow trout (Oncorhynchus mykiss). Fish Shellfish Immunol 30(2): 451-455.

25. Liaghat M, Akhlaghi M, Hosseini A, Nematollahi A, Hosseini SM (2011) Humoral and non-specific immune responses in rainbow trout (Oncorhynchus mykiss) naturally exposed to and immunized with Streptococcus iniae. Int J Vet Res 5(4): 218-224.

26. Yin G, Adro KD, Thompson A, Adams A, Jeney Z, et al. (2009) Chinese herbs (Astragalus radix and Gonoderma lucidum) enhance immune response of carp, Cyprinus carpio and protection against Aeromonas hydrophila. Fish Shellfish Immunol 26(1): 140-145

27. Harikrishnan R, Balasundaram C, Heo MS (2010) Herbal supplementation diets on hematology and innate immunity in goldfish against Aeromonas hydrophila. Fish Shellfish Immunol 28(2): 354-361.

28. Uribe C, Folch H, Enriquez R, Moran G (2011) Innate and adaptive immunity in teleost fish: a review. Vet Medicina 10: 486-503.

29. Dügenci KS, Arda N, Candan A (2003) Some medicinal plants as immunostimulant for fish. J Ethnopharmacol 88(1): 99-106.

30. Haghighi M, Sharifrohani M (2013) The effects of powdered ginger (Zingiber officinale) on the haematological and immunological parameters of rainbow trout Oncorhynchus mykiss. JMPHTR 1: 8-12.

31. Rao YV, Das BK, Pradhan J, Chakrabarti R (2006) Effect of Achyranthes aspera on the immunity and survival of Labeo rohita infected with Aeromonas hydrophila. Fish Shellfish Immunol 20(3): 263-273.

32. Choi SH, Park KH, Yoon TJ, Kim JB, Jang YS, et al. (2008) Dietary Korean mistele to enhances cellular non-specific immune responses and survival of Japanese eel (Anguilla japonica). Fish Shellfish Immunol 24: 67-73.

33. Bazari MS, Haghighi M, Sharif RM, Hamidi M, Ghasemi M (2017) The effects of different levels of Aloe vera extract on some of the hematological and non-specific immune parameters in Siberian sturgeon (Acipenser baerii). Iranian Journal of Fisheries Sciences 16(4): 1234-1247.

\begin{tabular}{l} 
Your next submission with Juniper Publishers \\
will reach you the below assets \\
- Quality Editorial service \\
- Swift Peer Review \\
- Reprints availability \\
- E-prints Service \\
- Manuscript Podcast for convenient understanding \\
- Global attainment for your research \\
- Manuscript accessibility in different formats \\
( Pdf, E-pub, Full Text, Audio) \\
- Unceasing customer service \\
Track the below URL for one-step submission \\
https://juniperpublishers.com/online-submission.php \\
\hline
\end{tabular}

